\title{
Potensi Simpanan Karbon Pada Lamun Cymodocea serrulata Di Pantai Prawean, Jepara
}

\author{
Tiara Nur Baeti ${ }^{\star}$, Retno Hartati, Ita Riniatsih \\ Departemen IImu Kelautan, Fakultas Perikanan dan IImu Kelautan, Universitas Diponegoro \\ Jl. Prof.H.Soedarto S.H, Tembalang,Semarang, Jawa Tengah 50275 Indonesia \\ ${ }^{*}$ Corresponding author, e-mail : tiara1403baeti@gmail.com
}

\begin{abstract}
ABSTRAK : Pemanasan global merupakan akibat dari peningkatan gas-gas rumah kaca (GRK), seperti halnya gas karbondioksida, metana, nitro dioksida, maupun gas alam lainnya. Ekosistem padang lamun di perairan Pantai Prawean, Kabupaten Jepara memiliki fungsi ekologis yang sangat penting sebagai penyangga ekosistem lain di perairan tersebut. Potensi padang lamun diantaraanya adalah sebagai penyimpan emisi karbon, sehingga mampu mencegah terjadinya pemanasan global (global warming) atau biasa disebut sebagai blue carbon. Tujuan penelitian ini adalah untuk menentukan potensi simpanan karbon pada lamun jenis Cymodocea serrulata di perairan Pantai Prawean, Kabupaten Jepara. Penelitian ini dilakukan pada bulan Desember 2018 dan Maret 2019 dengan metode pengukuran karbon pada lamun Loss of Ignition (LOI). Hasil penelitian menunjukkan bahwa biomassa terbesar terletak pada bagian Below Ground (akar dan rhizoma) dengan persentase di atas $50 \%$ pada kedua waktu pengamatan bila dibandingkan dengan jaringan lamun di atas substrat (daun). Rata-rata kandungan karbon tertinggi pada kedua waktu penelitain terletak pada bagian akar lamun dengan persentase nilai simpanan karbon mencapai $55-57 \%$. Terjadi penurunan nilai simpanan karbon dalam dua kali pengambilan data, yakni pada bulan Desember 2018 total simpanan karbon pada lamun Cymodocea serrulata mencapai 6,77 ton sedangkan pada bulan Maret 2019 nilainya turun menjadi 5,38 ton. Penurunan total simpanan karbon pada lamun ini di duga diakibatkan oleh adanya perubahan faktor fisik perairan serta adanya faktor antropogenik di wilayah perairan tersebut.
\end{abstract}

Kata Kunci: Biomassa; C. serrulata; Pantai Prawean; Simpanan Karbon

\section{Potential Carbon Deposits in Seagrass Cymodocea serrulata On Prawean Beach, Jepara}

ABSTRACT : Global warming is a result of increasing greenhouse gases (GHG), such as carbon dioxide, methane, nitrous dioxide, and other natural gas. Seagrass ecosystems in the waters of Prawean Beach, Jepara Regency have very important ecological functions as a buffer for other ecosystems in these waters. The potential of seagrass bed is as a store of carbon emissions, so as to prevent global warming or commonly referred to as blue carbon. The purpose of this research is to determine the potention of carbon deposits in seagrass species of Cymodocea serrulata in the waters of Prawean Beach, Jepara Regency. This research was conducted in December 2018 and March 2019 with the method of carbon measurement in seagrass Loss of Ignition (LOI). The results showed that the largest biomass was located in the Below Ground (roots and rhizomes) with a percentage above $50 \%$ at both observation time when compared to seagrass tissue on the substrate (leaves). The highest average carbon content at both time of the survey was located in the seagrass root section with a percentage of the value of carbon deposits reaching $55-57 \%$. There was a decrease in the value of carbon deposits in two data collection, namely in December 2018 the total carbon deposits in seagrass Cymodocea serrulata reached 6,77 tons while in March 2019 the value dropped to 5,38 tons. The decrease in total carbon deposits in seagrasses is thought to be caused by changes in physical factors of the waters and the presence of anthropogenic factors in these waters.

Keywords: Biomass; Cymodocea serrulata; Prawean beach; Carbon Stock 


\section{PENDAHULUAN}

Kegiatan manusia seperti aktivitas industri dan transportasi yang menggunakan bahan bakar fosil merupakan faktor utama terjadinya peningkatan konsentrasi gas rumah kaca di atmosfer, terutama gas $\mathrm{CO}_{2}$. Dampak yang ditimbulkan dari peristiwa peningkatan $\mathrm{CO}_{2}$ di atmosfer diantaranya adalah peningkatan suhu bumi, perubahan curah hujan, peningkatan kejadian iklim dan cuaca yang ekstrim, serta naiknya suhu dan tinggi muka air laut (TML). Perubahan kondisi tersebut jelas akan mempengaruhi kelangsungan hidup manusia dan makhluk lainnya di muka bumi (Hairiah et al., 2016).

Laut memiliki peran penting dalam menyerap $\mathrm{CO}_{2}$ di atmosfer. Menurut Feely et al. (2006), lautan telah menyerap 525 miliar ton karbon dioksida dari atmosfer, atau hampir setengah dari emisi karbon bahan bakar fosil selama 200 tahun terakhir. Kemampuan ini didukung dengan adanya peristiwa fotosintesis yang dilakukan oleh fitoplankton serta tumbuhan laut, seperti halnya lamun.

Lamun (seagrass) adalah tumbuhan berbunga (Angiospermae) yang seluruh proses kehidupannya berlangsung di lingkungan perairan laut dangkal. Tumbuhan lamun di perairan laut umumnya membentuk suatu ekosistem yang disebut dengan padang lamun. Lamun yang hidup secara terendam didalam perairan dapat melakukan fotosintesis seperti halnya tumbuhan di darat. Proses fotosintesis ini menghasilkan bahan organik dari bahan anorganik berupa karbon, yang kemudian disimpan pada biomassa (Rustam et al., 2014) dan disebut dengan blue carbon.

Karbon yang diserap oleh lamun dan disimpan dalam bentuk biomassa tersebut nantinya akan di distribusikan ke seluruh wilayah ekosistem lamun, terutama pada bagian substrat, dalam jangka waktu yang sangat lama dan sangat bermanfaat bagi fungsi ekologis maupun ekonominya (Supriadi et al., 2012). Menurut Rustam et al. (2014), jenis lamun yang memiliki peran besar dalam penyimpanan karbon adalah Enhalus acoroides, Cymodocea serrulata dan Syringodium isoetifolium dengan potensi Enhalus acoroides sebesar $35,43 \mathrm{gC} / \mathrm{m}^{2}$, Cymodocea serrulata 12,40 $\mathrm{gC} / \mathrm{m}^{2}$ dan Syringodium isoetifolium $7,93 \mathrm{gC} / \mathrm{m}^{2}$.

Perairan Pantai Prawean, Kabupaten Jepara, yang terletak di bagian timur dari Pantai Bandengan diketahui terdapat ekosistem padang lamun, sehingga di daerah tersebut berpotensi sebagai penyimpan karbon. Jenis lamun yang mendominasi di wilayah tersebut adalah jenis Cymodocea serrulata (Riniatsih, 2015; Septiani et al., 2018). Perairan pantai tersebut digunakan sebagai daerah penangkapan ikan oleh penduduk setempat, serta sebagai lokasi persinggahan kapal wisata dari Pantai Bandengan ke Pulau Panjang. Kegiatan-kegiatan tersebut diduga akan berdampak pada potensi lamun di Pantai Prawean sebagai penyimpan karbon.

\section{MATERI DAN METODE}

Materi yang digunakan dalam penelitian ini adalah lamun jenis Cymodocea serrulata yang terdapat di perairan Pantai Prawean, Kabupaten Jepara. Penelitian ini terbahi menjadi dua, yakni penelitian lapangan yang dilakukan di Pantai Prawean, Kab. Jepara dan penelitian laboratorium yang dilakukan di Laboratorium Potong Fakultas Pertanian dan Peternakan Universitas Diponegoro, Semarang.

Proses pengambilan data pada penelitian ini dilaksanakan sebanyak dua kali, yakni pada bulan Desember 2018 dan bulan Maret 2019. Penentuan lokasi dilakukan dengan menggunakan metode Purposive sampling, yakni dengan berdasarkan pada karakteristik tertentu, yakni keberadaan lamun Cymodocea serrulata di lokasi tersebut.

Pengambilan data lamun dilakukan dengan menggunakan metode monitoring padang lamun oleh Rahmawati et al. (2014). Line transect quadrant dibentang secara tegak lurus terhadap garis pantai kearah laut sepanjang 100 meter, yang dimulai dari titik 0 (nol) atau tempat pertama kali ditemukannya lamun yang paling dekat dengan garis pantai. Jarak antar sub stasiun adalah 50 meter, atau disesuaikan dengan luas padang lamun yang ada. Jarak antar transek pada setiap sub-stasiun adalah 10 meter. Luas keseluruhan transek yang digelar yakni $100 \mathrm{~m} \times 100 \mathrm{~m}$ atau $10.000 \mathrm{~m}^{2}$. Pendataan lamun dilakukan dengan menggunakan transek kuadran berukuran $1 \times 1 \mathrm{~m}$.

Pengamatan terhadap parameter fisik perairan juga dilakukan dalam pengambilan data lapangan. Parameter fisik yang diukur meliputi suhu, salinitas, $\mathrm{pH}$, kecerahan, dan ukuran butir substrat. 
Lamun dari jenis Cymodocea serrulata yang terdapat pada transek di titik $0 \mathrm{~m}, 50 \mathrm{~m}$, dan $100 \mathrm{~m}$ di setiap line di ambil dengan menggunakan metode cuplikan (Graha, 2015). Pencuplikan sampel lamun dilakukan disetiap titik pengamatan (transek kuadrat) dengan 3 kali pengulangan. Spesimen yang telah diambil kemudian dibersihkan dari substrat maupun epifit yang menempel dengan menggunakan air tawar bersih, kemudian dipisahkan berdasarkan jenis dan dipotong menjadi tiga bagian, yakni daun, rhizome dan akarnya. Pemisahan bagian pada sampel lamun ini dilakukan untuk mengetahui potensi simpanan karbon dalam biomassa di atas substrat (above ground) dan di bawah substrat (below ground).

Sampel lamun dipisahkan menjadi tiga, yakni daun, rhizome dan akarnya, kemudian setiap bagian tersebut ditimbang terlebih dahulu untuk mengetahui berat basah sampel. Pengeringan dilakukan dengan cara memasukkan sampel yang telah terbungkus alumunium foil ke dalam oven pada temperatur tetap $105-110^{\circ} \mathrm{C}$ selama 4-6 jam hingga mencapai berat konstan, kemudian di dinginkan dalam desikator selama 15 menit kemudian ditimbang, sehingga diperoleh hasil akhir untuk masing-masing bagian tersebut dalam satuan gram berat kering/meter ${ }^{2}$. Pengukuran biomassa per tegakan lamun dapat diketahui dengan membagi berat total setiap sampel dengan jumlah tegakannya (kerapatan). Hubungan antara kerapatan dan biomassa lamun digunakan untuk memprediksi biomassa lamun pada semua titik sampling kepadatan yang dilakukan (Supriadi et al., 2011).

Sampel dianalisis kandungan karbon organiknya dengan metode pengabuan atau LOI (Loss of Ignition) (Fourqurean et al., 2014). Pengabuan dilakukan dengan menggunakan tanur/furnace selama $4-6$ jam dengan suhu $550^{\circ} \mathrm{C}$ sehingga sampel berubah menjadi berbentuk abu putih. Tanur dimatikan, kemudian di tunggu hingga suhu $<120^{\circ} \mathrm{C}$. Cawan didinginkan dalam desikator selama 15 menit, kemudian ditimbang, sehingga diperoleh berat abu pada sampel. Kerapatan lamun (D) dihitung dengan menggunakan rumus Brower et al. (1990) berikut:

$$
\mathrm{D}=\sum \frac{n i}{A}
$$

Keterangan : $\mathrm{D}=$ Kerapatan jenis $\left(\right.$ tegakan $\left./ \mathrm{m}^{2}\right) ; \mathrm{Ni}=$ Jumlah tegakan jenis i (tegakan); $\mathrm{A}=$ Luas daerah yang disampling $\left(\mathrm{m}^{2}\right)$

Persen tutupan (\% cover) lamun dianalisa dengan menggunakan rumus:

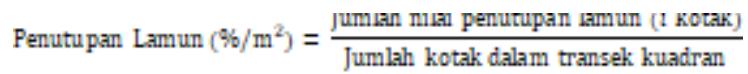

Perhitungan indeks keanekaragaman $(\mathrm{H})$ dilakukan berdasarkan pada rumus ShannonWeaner (Kamaruddin et al., 2016) adalah sebagai berikut:

$$
\mathrm{H}^{s}=-\sum_{\mathrm{i}=1}^{\mathrm{n}}(p i \ln p i)
$$

Keterangan : $\mathrm{H}^{\prime}$ = Indeks keanekaragaman Shannon- Weaner; $\mathrm{Pi}=\mathrm{ni} / \mathrm{N} ; \mathrm{ni}=$ Jumlah individu dari suatu jenis ke-l; $\mathrm{N}=$ Jumlah total individu seluruh jenis

Mason (1981), menggolongkan hasil perhitungan indeks keanekaragaman tersebut ke dalam tiga golongan, yakni: $H^{\prime}>3$ = keanekaragaman spesies pada suatu transek adalah tinggi $H^{\prime} 1 \leq$ $H^{\prime} \leq 3=$ keanekaragaman spesies pada suatu transek adalah sedang $H^{\prime}<1=$ keanekaragaman jenis rendah.

Indeks keseragaman Eveness (E) perlu diketahui untuk dapat mengetahui kesamaan dalam persebaran jenis lamun yang sama dengan membandingkan indeks keanekaragamannya dengan nilai maksimum dari indeks keanekaragaman secara keseluruhan (Suhud et al., 2013). Indeks keseragaman dihitung dengan menggunakan rumus berikut:

$$
\mathrm{E}=\frac{\mathrm{H}^{\mathrm{v}}}{\mathrm{H}_{\max }} \quad ; \quad \mathrm{H}_{\max }=\ln \mathrm{S}
$$

Hasil perhitungan indeks keseragaman kemudian dibandingkan dengan penggolongannya, yakni apabila $E<0,4$ maka ekosistem tersebut berada dalam kondisi tertekan dan mempunyai 
keseragaman rendah; 0,4 $<\mathrm{E}<0,6$ maka ekosistem tersebut pada kondisi kurang stabil dan mempunyai keseragaman sedang serta apabila $E>0,6$ maka ekosistem tersebut dalam kondisi stabil dan mempunyai keseragaman tinggi.

Indeks dominansi (D) dihitung untuk mengetahui apakah spesies lamun tertentu mendominasi di wilayah penelitian tersebut. Perhitungan indeks dominansi dilakukan dengan rumus dominansi Simpson, di mana kisaran dominansi yaitu $0,00<D<0,50$ berarti dominansi rendah, nilai $0,50<D<0,75$ dominansi sedang, serta nilai $0,57<D<1,00$ berarti dominansi tinggi (Dhembare, 2011). Rumus dominansi yang digunakan adalah sebagai berikut:

$$
\mathrm{D}=\sum_{\mathrm{i}=1}^{\mathrm{n}} \mathrm{Pi}^{2}
$$

Keterangan : $\mathrm{D}$ = Indeks Dominansi Simpson; $\mathrm{Pi}=\mathrm{ni} / \mathrm{N} ; \mathrm{ni}=$ Jumlah individu dari suatu jenis ke-l; $\mathrm{N}=$ Jumlah total individu seluruh jenis

\section{Perhitungan Biomassa dan Karbon pada Lamun Cymodocea serrulata}

Biomassa pada lamun Cymodocea serrulata diukur dengan menggunakan rumus yang dirujuk dari Azkab (1999), sebagai berikut:

$$
B=W \times D
$$

Keterangan : $B=$ Biomassa lamun $\left(\mathrm{gbk} / \mathrm{m}^{2}\right) ; \mathrm{W}=$ Berat kering dari satu tegakan lamun (gbk/tegakan); D = Kerapatan lamun (tegakan $/ \mathrm{m}^{2}$ )

Perhitungan bahan organik yang terdapat pada sampel lamun dapat dilakukan dengan menggunakan persamaan oleh Helrich (1990), sebagai berikut:

$$
\text { Kadar Bahan Organik }=\frac{[(b-a)-(c-a)]}{b-a} \times 100 \%
$$

Keterangan : $a=$ Berat cawan; $\mathrm{b}=$ Berat cawan + berat kering jaringan lamun; $\mathrm{c}=$ Berat cawan + berat abu jaringan lamun

Perhitungan nilai karbon pada jaringan lamun dihitung dengan menggunakan persamaan Helrich (1990), untuk kemudian dirata-rata sebagai nilai kandungan karbon yang terdapat pada jaringan tumbuhan lamun (Graha, 2015). Persamaan untuk perhitungan nilai karbon pada jaringan lamun adalah sebagai berikut:

$$
\text { Kandungan Karbon }=\frac{\text { Kadar Bahan Organik }}{1,724}
$$

Keterangan :1,724 = Konstanta untuk mengkonversi \% bahan organik menjadi \% C.

\section{Perhitungan Total Stok Karbon}

Total simpanan karbon padalamun Cymodocea serrulata di perairan Pantai Prawean, Kab. Jepara dapat diketahui dengan persamaan oleh Sulaeman et al. (2005), sebagai berikut:

$$
\mathrm{Ct}=\Sigma(\mathrm{Li} \times \mathrm{Ci})
$$

Keterangan : $\mathrm{Ct}=$ Karbon total $(\mathrm{gC}) ; \mathrm{Li}=$ Luas padang lamun kategori kelas $\mathrm{i}\left(\mathrm{m}^{2}\right) ; \mathrm{Ci}=$ Rata-rata stok karbon lamun kategori kelas $\mathrm{i}\left(\mathrm{gC} / \mathrm{m}^{2}\right)$

\section{HASIL DAN PEMBAHASAN}

Karakteristik Pantai Prawean memiliki arus dan gelombang yang cukup tenang karena berada di wilayah pantai utara jawa, serta terdapat Pulau Panjang yang lokasinya tepat di seberang lokasi tersebut. Pantai Prawean memiliki pantai yang landai, dan kedalaman di lokasi tersebut berkisar antara 0,5-1,5 meter. Hasil yang diperoleh dari pengukuran parameter fisik perairan ditunjukkan pada Tabel 1, 
Hasil pengukuran kecerahan di perairan tersebut menunjukkan adanya penurunan tingkat kecerahan pada pengamatan kedua, yakni di bulan Maret 2019. Hal tersebut dapat diakibatkan bertambahnya proses sedimentasi akibat adanya aktivitas pembangunan di wilayah pesisir pantai. Tingginya sedimentasi yang terjadi juga menyebabkan perubahan pada persentase jenis sedimen, di mana nilai persentase pasir halus dan lanau menjadi lebih tinggi apabila dibandingkan dengan pengamatan pada bulan Desember 2018.

\section{Komposisi Jenis, Kerapatan, dan Persentase Tutupan Lamun di Pantai Prawean}

Berdasarkan hasil pengamatan yang telah dilakukan di satu stasiun penelitian, dapat diketahui bahwa di lokasi tersebut terdapat empat jenis lamun, yakni Enhalus acoroides, Thalassia hemprichii, Cymodocea serrulata dan Cymodocea rotundata. Lamun jenis Thalassia hemprichii hanya ditemukan pada bulan Desember 2018.

Tabel 1. Rata-rata hasil pengukuran parameter perairan Pantai Prawean, Kabupaten Jepara

\begin{tabular}{lccc}
\hline \multirow{2}{*}{ Parameter } & $\begin{array}{c}\text { Baku Mutu } \\
\text { (KepMen Lingkungan Hidup } \\
\text { Nomor 200 Tahun 2004) }\end{array}$ & Desember 2018 & Maret 2019 \\
\cline { 3 - 4 } & $28-30$ & 30,1 & 30,3 \\
Suhu $\left({ }^{\circ} \mathrm{C}\right)$ & $33-34$ & 33,7 & 33 \\
Salinitas (\%o) & $7-8,5$ & 8 & 8 \\
pH & - & 92,1 & 86,9 \\
Kecerahan & - & Kerikil 20,58 & Kerikil 5,48 \\
$(\%)$ & & Pasir kasar 20,00 & Pasir kasar 10,82 \\
Substrat (\%) & & Pasir halus 46,76 & Pasir halus 60,29 \\
& & Lanau 12,66 & Lanau 23,41 \\
\hline
\end{tabular}

Tabel 2. Jenis lamun yang ditemukan di Pantai Prawean, Kab. Jepara pada pendataan bulan Desember 2018 dan Maret 2019

\begin{tabular}{lcc}
\hline \multicolumn{1}{c}{ Jenis Lamun } & \multicolumn{2}{c}{ Waktu Pendataan } \\
\cline { 2 - 3 } & Desember 2018 & Maret 2019 \\
\hline Enhalus acoroides & + & + \\
Thalassia hemprichii & + & - \\
Cymodocea serrulata & + & + \\
Cymodocea rotundata & + & + \\
\hline Jumlah Spesies & 4 & 3 \\
\hline
\end{tabular}

(Keterangan : + : Ditemukan; - : Tidak Ditemukan)

Jenis lamun yang paling mendominasi di antara keempat jenis yang ditemukan yaitu jenis Cymodocea serrulata, di mana nilai kisaran kerapatan yang diperoleh pada pengamatan pertama (Desember 2018), yakni mencapai $175-528$ individu $/ \mathrm{m}^{2}$ kerapatan dari jenis lamun lain yang ditemukan diantaranya adalah sebagai berikut: Enhalus acoroides $16-48$ individu/ $\mathrm{m}^{2}$, Thalassia hemprichii 56-152 individu/ $\mathrm{m}^{2}$ dan Cymodocea rotundata 32-88 individu/ $\mathrm{m}^{2}$.

Nilai kerapatan lamun pada pengamatan di bulan Maret 2019 mengalami penurunan. Nilai kerapatan lamun jenis Cymodocea serrulata masih paling mendominasi, dengan nilai kerapatan sebesar 184-592 individu/m². Kerapatan lamun jenis Enhalus acoroides 12 individu/m² dan Cymodocea rotundata $80-100 \mathrm{individu} / \mathrm{m}^{2}$.

Persentase tutupan (\% cover) lamun tiap jenis pada lokasi pengamatan pada bulan Desember 2018 yakni Enhalus acoroides 2,7\%, Cymodocea serrulata 62,7\%, Cymodocea rotundata 1,2\% serta Thalassia hemprichii 2,3\%. Pada bulan Maret 2019, nilai persentase tutupan lamun terjadi perubahan, yakni Enhalus acoroides 4,2\%, Cymodocea serrulata $60,2 \%$, serta Cymodocea rotundata $0,5 \%$. 


\section{Biomassa dan Total Simpanan Karbon Lamun Cymodocea serrulata}

Nilai biomassa pada lamun Cymodocea serrulata yang diamati terbagi menjadi dua, yakni nilai biomassa yang terdapat diatas substrat seperti daun, serta nilai biomassa yang terdapat di bawah substrat yakni rhizome dan akar. Kisaran nilai biomassa total dari lamun yang terdapat di lokasi penelitian yang diperoleh pada pengamatan pertama (Desember 2018) adalah sebesar $144,66-317,83 \mathrm{gram} / \mathrm{m}^{2}$, dengan rata-rata dari biomassa atas substrat sebesar $101,54 \mathrm{gram} / \mathrm{m}^{2}$ serta biomassa bawah substrat $122,22 \mathrm{gram} / \mathrm{m}^{2}$. Berdasarkan hasil yang diperoleh, dapat diketahui bahwa persentase biomassa lamun di atas substrat adalah $45 \%$ atau lebih kecil dibandingkan biomassa lamun di bawah substrat, yakni sebesar 55\%.

Hasil pengambilan data kedua (Maret 2019), kisaran nilai total dari biomassa adalah 137,64$231,52 \mathrm{gram} / \mathrm{m}^{2}$, dengan rata-rata total biomassa di atas substrat sebesar $89,12 \mathrm{gram} / \mathrm{m}^{2}$ serta biomassa bawah substrat $92,83 \mathrm{gram} / \mathrm{m}^{2}$. Berdasarkan hasil yang diperoleh, dapat diketahui perbandingan persentase nilai biomassa di bagian atas substrat adalah $49 \%$, sedangkan nilai persentase biomassa bawah substrat adalah $51 \%$.

Berdasarkan hasil penelitian yang telah dilakukan, dapat diketahui bahwa pada kedua waktu pendataan, nilai biomassa pada bagian lamun Cymodocea serrulata yang berada bawah substrat (rhizome dan akar) lebih tinggi dari bagian lamun yang berada di atas substrat (daun). Perbandingan nilai biomassa tersebut sesuai dengan penelitian yang dilakukan oleh Rustam et al. (2014), di mana nilai biomassa Cymodocea serrulata pada bagian bawah substrat lebih besar dari bagian atas substrat. Tingginya nilai biomassa pada bagian lamun di bawah substrat juga diduga berhubungan erat dengan adanya efek positif dari substrat lumpur organik terhadap perkembangan sistem penyerapan nutrien pada tipe sedimen (Christon et al., 2012). Bahan organik yang terdapat pada substrat di dasar perairan berasal dari jaringan organik tanaman, seperti halnya lamun.

Tabel 3. Hasil rata-rata pengamatan kondisi kerapatan (ind $/ \mathrm{m}^{2}$ ) dan persentase tutupan lamun (\%) pada kedua waktu pendataan

\begin{tabular}{lcccc}
\hline \multirow{2}{*}{ Jenis Lamun } & \multicolumn{2}{c}{ Desember 2018 } & \multicolumn{2}{c}{ Maret 2019 } \\
\cline { 2 - 5 } & Kerapatan (ind $\left./ \mathrm{m}^{2}\right)$ & $\%$ cover & Kerapatan (ind $\left./ \mathrm{m}^{2}\right)$ & $\%$ cover \\
\hline E. acoroides & 3 & 2,7 & 1 & 4,2 \\
C. serrulata & 338 & 62,3 & 314 & 60,2 \\
C. rotundata & 5 & 1,2 & 11 & 0,5 \\
T. hempricii & 8 & 2,3 & - & - \\
\hline Jumlah & 354 & 68,5 & 326 & 64,8 \\
\hline
\end{tabular}
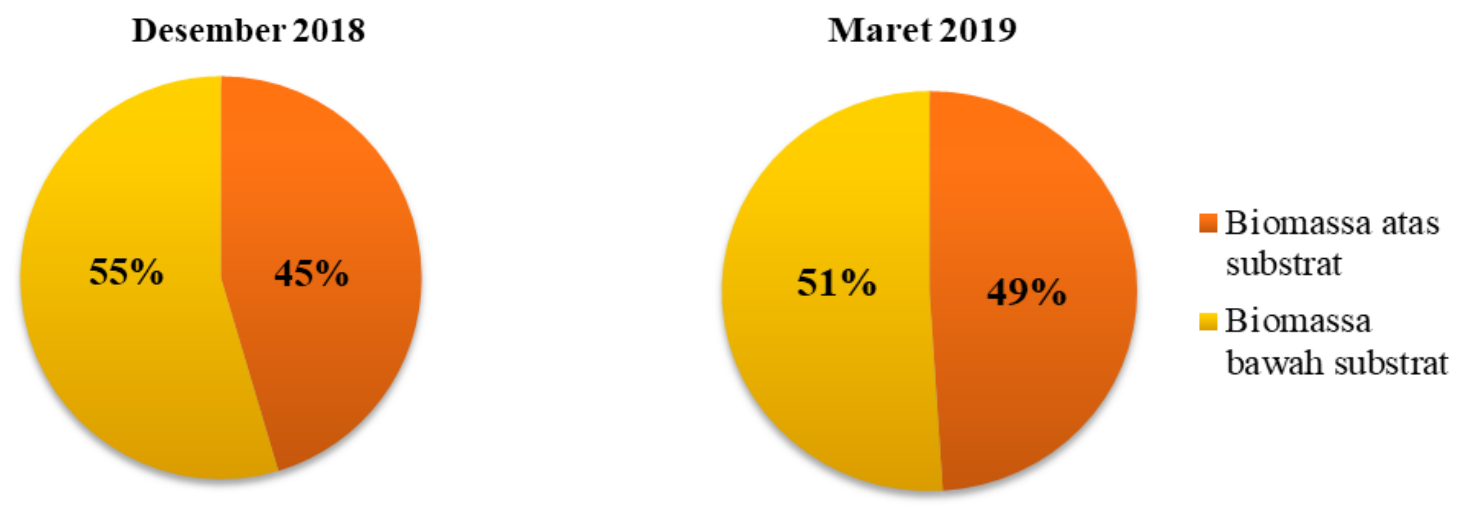

Gambar 1. Diagram persentase biomassa lamun di atas substrat dan di bawah substrat pada periode pengamatan I dan II 
Hasil perhitungan nilai biomassa yang diperoleh dari penelitian ini menunjukkan adanya penurunan kandungan biomassa pada jaringan lamun di pendataan pada bulan Maret 2019. Penurunan ini diduga terjadi akibat adanya perubahan kondisi fisik perairan, yang salah satunya adalah adanya perubahan salinitas dan berdampak pada kemampuan fotosintesis lamun. Apabila terjadi penurunan pada salinitas perairan, maka kemampuan lamun dalam berfotosintesis juga akan terganggu. Pengaruh lain dari perubahan salinitas perairan diantaranya berdampak pada biomassa, produktivitas primer, kerapatan, lebar daun dan kecepatan pulih (Herkul dan Kotta, 2009).

Data hasil pengamatan bulan Desember 2018, nilai kandungan karbon yang terdapat di atas substrat berkisar antara 17,09-67,69 $\mathrm{gC} / \mathrm{m}^{2}$, sedangkan untuk kandungan karbon di bawah substrat sebesar $31,33-73,02 \mathrm{gC} / \mathrm{m}^{2}$. Kisaran nilai kandungan karbon pada bulan Maret 2019 adalah $20,29-31,79 \mathrm{gC} / \mathrm{m}^{2}$ untuk karbon di atas substrat dan $22,18-53,46 \mathrm{gC} / \mathrm{m}^{2}$ untuk nilai kandungan karbon di bawah substrat.

Hasil perhitungan total stok karbon lamun di bawah substrat pada bulan Desember 2018 sebesar $383,75 \mathrm{gC} / \mathrm{m}^{2}$, atau $57 \%$ lebih besar dibandingkan dengan total stok karbon lamun di atas substrat yang hanya $43 \%$ dengan total $293,37 \mathrm{gC} / \mathrm{m}^{2}$. Nilai total stok karbon di bawah substrat pada bulan Maret 2019 sebesar 294,98 gC/m $\mathrm{m}^{2}$ atau 55\% total simpanan karbon, dan nilai stok karbon lamun di bagian atas substrat adalah $243,17 \mathrm{gC} / \mathrm{m}^{2}$ atau $45 \%$ dari total simpanan karbon di wilayah tersebut.

Berdasarkan hasil perhitungan rata-rata total simpanan karbon lamun Cymodocea serrulata dengan luas transek yang digelar saat pendataan $\left(100 \mathrm{~m} \times 100 \mathrm{~m}=10.000 \mathrm{~m}^{2}=1\right.$ hektar $)$, maka akan diketahui terjadinya penurunan potensi simpanan karbon total pada lamun Cymodocea serrulata di bulan Desember 2018 dan pada bulan Maret 2019 dalam ton/hektar, yang disajikan pada Tabel 4.

Berdasarkan Table 4, dapat diketahui bahwa terjadi penurunan total simpanan karbon pada pendataan kedua di Pantai Prawean. Terjadinya penurunan tersebut juga diduga diakibatkan oleh adanya faktor antropogenik, atau faktor yang diakibatkan oleh adanya kegiatan manusia, seperti halnya aktivitas pelayaran, di mana Pantai Prawean merupakan lokasi persinggahan kapal-kapal wisata yang beroperasi di Bandengan dan Pulau Panjang. Kegiatan reklamasi, atau penimbunan wilayah pantai karena adanya pembangunan di wilayah pesisir Pantai Prawean juga menjadi penyebab menurunnya total simpanan karbon di perairan tersebut. Kurangnya pengetahuan masyarakat mengenai fungsi padang lamun sebagai penyerap karbon juga merupakan penyebab utama terjadinya penurunan potensi padang lamun Pantai Prawean sebagai blue carbon.

Tabel 4. Hasil perhitungan nilai total simpanan karbon lamun Cymodocea serrulata pada bulan Desember 2018 dan Maret 2019

Waktu Pengamatan

Desember 2018

Maret 2019
Atas Substrat

0,33 ton

0,27 ton
Bawah Substrat

0,43 ton

0,33 ton
Total Stok Karbon

0,76 ton

0,60 ton

\section{KESIMPULAN}

Lamun yang ditemukan di perairan Pantai Prawean terdapat empat spesies, yakni Enhalus acoroides, Thalassia hempricii, Cymodocea serrulata dan Cymodocea rotundata. Jenis lamun yang paling dominan di perairan tersebut adalah Cymodocea serrulata. Nilai total karbon lamun dari jenis Cymodocea serrulata yang tersimpan di perairan Pantai Prawean adalah 0,76 ton/hektar pada bulan Desember 2018 dan 0,60 ton/hektar pada bulan Maret 2019. Terjadinya penurunan nilai total simpanan karbon di perairan tersebut diakibatkan oleh aktivitas antropogenik dan adanya perubahan kondisi fisik perairan, terutama kecerahan, yang dapat mempengaruhi pertumbuhan dan kerapatan lamun di perairan tersebut. 


\section{DAFTAR PUSTAKA}

Azkab, M.H. 1999. Pedoman Inventarisasi Lamun. Oseana, 24(1):1-16.

Brower, J. E., Zar, J. H. \& Von Ende, C. 1990. General Ecology. Field and Laboratory Methods. Wm. C. Brown Company Publisher, Dubuque, lowa.

Dhembare, A.J. 2011. Diversity and its Indices of Macroinvertebrates from Dynaneshwar Water Rahuri, Ahmednagar, Maharashtra, India. Science Research, 2(6):223-228.

Feely, R.A., Christopher, L.S., \& Victoria, J.F. 2006. Carbon Dioxide and Our Ocean Legacy. Science, 305 (5682):362-366.

Fourqurean, J., Johnson, B., Kauffman, J.B., Kennedy, H. \& Lovelock, C. 2014. Field Sampling of Soil Carbon Pools in Coastal Ecosystems. Conservation International, Intergovernmental Oceanographic Commission, IUCN.Arlington, Virginia.

Graha, Y.I. 2015. Simpanan Karbon Padang Lamun di Kawasan Pantai Sanur, Kota Denpasar. [Thesis]. Program Pascasarjana, Universitas Udayana, Bali.

Hairiah, K., Subekti, R., Didik, S. \& Cahyo, P. 2016. Perubahan Iklim: Sebab dan Dampaknya Terhadap Kehidupan. Bahan Ajar 1. Bogor, Indonesia: World Agroforestry Centre (ICRAF) Southeast Asia Regional Program dan Malang. Universitas Brawijaya, Malang.

Herkul, K., \& Kotta, J. 2009. Effects of Eelgrass (Zostera marina) Canopy Removal and Sediment Addition on Sediment Characteristics and Benthic Communities in the Northern Baltic Sea. Marine Ecology, 30:74-82

Kamaruddin, Z.S., Rondonuwu, S.B. \& Maabuat, P.V. 2016. Keragaman Lamun (Seagrass) di Pesisir Desa Lihunu Pulau Bangka Kecamatan Likupang Kabupaten Minahasa Utara, Sulawesi Utara. Jurnal Mipa Unsrat Online, 5(1):20-24.

Rahmawati, S., Irawan, A., Supriyadi, I.H. \& Azkab, M.H. 2014. Panduan Monitoriong Padang Lamun. COREMAP CTI LIPI 2014, Jakarta, $37 \mathrm{hlm}$

Riniatsih, I. 2015. Distribusi Muatan Padatan Tersuspensi (MPT) di Padang Lamun di Perairan Teluk Awur dan Pantai Prawean Jepara. Jurnal Kelautan Tropis Desember, 18 (3): 121-126.

Rustam, A., Terry, L.K., Restu, N.A., Hadiwijaya, L.S., Mariska, A., August, D., Peter, M., Nasir, S., Yusmiana, P.R., Devi, D.S. \& Andreas, H. 2014. Peran Lamun sebagai Blue Carbon dalam Mitigasi Perubahan Iklim, Studi Kasus Tanjung Lesung, Banten. Balitbang Kelautan dan Perikanan, Kementerian Kelautan dan Perikanan.

Septiani, E.F., Abdul G., \& Sigit F. 2018. Pemetaan Karbon di Padang Lamun Pantai Prawean Bandengan Jepara. Majalah IImiah Globe, 20(2):117-124

Suhud, M.A., Pratomo, A. \& Yandri, F. 2013. Struktur Komunitas Lamun Di Perairan Pulau Nikoi. Universitas Maritim Raja Ali Haji.

Sulaeman, Suparto \& Eviati. 2005. Petunjuk Teknis Analisis Tanah, Tanaman, Air dan Pupuk. Balai Penelitian Tanah, Badan Penelitian dan Pengembangan Pertanian, Departemen Pertanian, Bogor.

Supriadi, Richardus, F. Kaswadji, Dietriech, G.B. \& Hutomo, M. 2011. Potensi Penyimpanan Karbon Lamun Enhalus acoroides Di Pulau Barranglompo Makassar. Universitas Hasanuddin, Makassar.

Supriadi, Richardus, F.K., Dietrich, G.B. \& Hutomo, M. 2012. Produktivitas Komunitas Lamun Di Pulau Barranglompo Makassar. Jurnal Akuatika, 3(2):159-168. 